\title{
Soybean Relative Maturity, Not Row Spacing, Affected Interseeded Cover Crops Biomass
}

\author{
Hans J. Kandel (D), Dulan P. Samarappuli, Kory L. Johnson and Marisol T. Berti *D \\ Department of Plant Sciences, North Dakota State University, Fargo, ND 58104, USA; \\ hans.kandel@ndsu.edu (H.J.K.); dulan.samarappuli@ndsu.edu (D.P.S.); johnsonkory14@gmail.com (K.L.J.) \\ * Correspondence: marisol.berti@ndsu.edu; Tel.: +1-701-231-6110
}

Citation: Kandel, H.J.; Samarappuli, D.P.; Johnson, K.L.; Berti, M.T.

Soybean Relative Maturity, Not Row Spacing, Affected Interseeded Cover Crops Biomass. Agriculture 2021, 11, 441. https://doi.org/10.3390/ agriculture11050441

Academic Editors: Stefano Tavoletti, Martin Weih and M. Inés Mínguez

Received: 20 April 2021

Accepted: 11 May 2021

Published: 13 May 2021

Publisher's Note: MDPI stays neutral with regard to jurisdictional claims in published maps and institutional affiliations.

Copyright: (c) 2021 by the authors. Licensee MDPI, Basel, Switzerland. This article is an open access article distributed under the terms and conditions of the Creative Commons Attribution (CC BY) license (https:/ / creativecommons.org/licenses/by/ $4.0 /)$.

\begin{abstract}
Adoption of cover crop interseeding in the northwestern Corn Belt in the USA is limited due to inadequate fall moisture for establishment, short growing season, additional costs, and need for adapted winter-hardy species. This study evaluated three cover crop treatments-no cover crop, winter rye (Secale cereale L.), and winter camelina (Camelina sativa (L.) Crantz)—which were interseeded at the R6 soybean growth stage, using two different soybean (Glycine max (L.) Merr.) maturity groups ( 0.5 vs. 0.9$)$ and two row spacings ( $30.5 \mathrm{vs} .61 \mathrm{~cm})$. The objective was to evaluate these treatments on cover crop biomass, soil cover, plant density, and soybean yield. Spring wheat (Triticum aestivum L.) grain yield was also measured the following year. The early-maturing soybean cultivar ( 0.5 maturity) resulted in increased cover crop biomass and soil cover, with winter rye outperforming winter camelina. However, the early-maturing soybean yielded $2308 \mathrm{~kg} \cdot \mathrm{ha}^{-1}$, significantly less compared with the later maturing cultivar $\left(2445 \mathrm{~kg} \cdot \mathrm{ha}^{-1}\right)$. Narrow row spacing had higher soybean yield, but row spacing did not affect cover crop growth. Spring wheat should not follow winter rye if rye is terminated right before seeding the wheat. However, wheat planted after winter camelina was no different than when no cover crop was interseeded in soybean. Interseeding cover crops into established soybean is possible, however, cover crop biomass accumulation and soil cover are limited.
\end{abstract}

Keywords: winter camelina; winter rye; soil cover; soybean cultivar; soybean maturity; wheat yield

\section{Introduction}

In the northern crop growing areas in the USA, crop rotations were simplified, and corn (Zea mays L.) and soybean (Glycine max (L.) Merr.) became dominant crops. As a result, ecosystem services delivery, due to this shift in farming system, declined [1]. For instance, after harvest, a soybean field has limited cover [2] and may result in soil erosion, mainly by wind. Including cover crops in the cropping system provides soil cover, increases biodiversity and soil organic matter, utilizes available nutrients by preventing leaching, and may increase growth and yield of the following crop [3]. Overwintering cover crops that resume growth in the spring in the northwestern Corn Belt (NWCB) were proven to provide many ecological beneficial attributes. Benefits, however, depend on cover crops growth to cover the soil [4-6]. Cover crop adoption is steadily increasing in farming operations across the United States, especially in the eastern Corn Belt [7].

One factor affecting the integration of cover crops into an existing crop is additional costs. These additional costs lead to the common economic challenges for cover crops of how to demonstrate a measurable economic return [8,9]. Corn and soybean in the NWCB region are harvested at the end of September through October, and the first fall frost can be expected also by the end September or in October. Therefore, the opportunity to seed cover crops after the harvest of the main crop is limited to years with early harvest and a late fall killing frost. Alternative methods of seeding cover crops before the main crop is harvested are needed for a successful cover crop establishment and enough time to accumulate biomass and cover the soil. 
Winter camelina (Camelina sativa (L.) Crantz) is an annual crop in the Brassicaceae family that has two distinct biotypes, spring and winter [10-12]. The interest in winter camelina as a cover crop increased since it is one of the few annual broadleaf cover crop that survives the winter in the NWCB and resumes growth in the spring [13-16].

Rye (Secale cereale L.) is the most used winter-hardy cover crop in the Midwest in the USA because it survives the winter, even when planted late in the growing season after the main crop harvest. In the spring, dormancy breaks, and rye resumes growth covering the soil before planting the following crop $[3,17,18]$. Rye minimum temperature for germination is $1{ }^{\circ} \mathrm{C}$, and vegetative growth starts at $3{ }^{\circ} \mathrm{C}$ [9]. In addition, due to the fibrous rye root system and the ability to take nitrate up, nutrient leaching can be reduced. Use of winter rye is a cost-effective strategy to reduce nitrate and phosphorus loading to water sources [19]. However, only recently, producers in the most northern USA production region are considering incorporating winter rye into their farming system.

Interseeding of cover crops into soybean at different growth stages was reported [15,20-22]. By growing an early-maturing soybean, it may be possible to give the cover crops more time in the fall to establish and grow. In addition, wider soybean rows are expected to allow more of the sunlight to penetrate the canopy. Interseeding can be done by direct seeding in between the rows with specialized equipment or broadcasting the cover crop seed before the main crop matures. Seeding before the main crop is mature gives the cover crop some additional time to grow before the fall-killing frost [23]. Producers want to be assured there is no yield penalty to the main crop when interseeding cover crops into the main crop nor yield reduction of the spring sown crop after terminating the winter hardy cover crop [9]. No previous research evaluated a combination of soybean maturity and row spacing on the establishment of cover crops in the NWCB.

This study evaluated the effects on cover crops interseeded into soybean, using two different soybean maturity groups and two row spacings. The objective was to evaluate the effects of these treatments on cover crops' (camelina and rye) biomass, soil cover, plant density, soybean yield, and subsequent wheat (Triticum aestivum L.) spring cover and grain yield.

\section{Materials and Methods}

\subsection{Experimental Design and Treatments}

A total of five experiments were conducted in North Dakota in 2017 and 2018 (Table 1). The experiments were conducted at an experimental site located at Fargo, ND $\left(46.932124^{\circ} \mathrm{N}, 96.858941^{\circ} \mathrm{W}\right)$. One experiment at Fargo was planted on soil that was tiledrained in 2008 with sub-surface perforated polyethylene tile lines placed at $100 \mathrm{~cm}$ depth with $7.6 \mathrm{~m}$ between tiles. Tile is commonly used in the Corn Belt in the USA. The second experiment at Fargo did not have tile drainage. Both soils at Fargo were naturally poorly or very poorly drained. The parent material of the soil was clayey glaciolacustrine deposits [24].

Table 1. Soil series, soil taxonomy, and slope at Fargo and Casselton, ND.

\begin{tabular}{cccc}
\hline Location & Soil Series $^{\dagger}$ & Taxonomic Class $^{\dagger}$ & Slope (\%) \\
\hline \multirow{2}{*}{ Fargo } & Fargo & Fine, smectitic, frigid Typic Epiaquerts & $0-1$ \\
and Ryan & Findred & Fine-silty, mixed, superactive, frigid & Typic Endoaquolls \\
Casselton & $\begin{array}{c}\text { Fine-silty, mixed, superactive, frigid } \\
\text { Aeric Calciaquolls }\end{array}$ & $0-2$ \\
\hline${ }^{\dagger}$ Soil data obtained from [24]. & And Bearden & &
\end{tabular}

The second location in 2017 was at Casselton, ND site $\left(46.880049^{\circ} \mathrm{N}, 97.246534^{\circ} \mathrm{W}\right)$. The parent material of the soil was fine-silty glaciolacustrine deposits [24] (Table 1). Weather data for the 2017 and 2018 growing seasons were obtained from the North Dakota Agricultural Weather Network [25]. 
Each separate experiment at each location and year was defined as an 'environment'. Each experiment had four replicates. Soil samples were taken at all sites just after the first killing frost in September. The soil is typically frozen from October to mid-April. Two soil samples, to depths of $0-15 \mathrm{~cm}$ and $15-61 \mathrm{~cm}$, were taken at each sampling location. Soil samples were tested for $\mathrm{NO}_{3}-\mathrm{N}$, Olsen $\mathrm{P}$ [26], $\mathrm{K}, \mathrm{pH}$, and organic matter (Table 2). Chemical fertilizer was not applied before or during the soybean growing season, as $\mathrm{P}$ and $\mathrm{K}$ soil test levels did not require fertilizer application. Soybean seed was inoculated to stimulate biological $\mathrm{N}_{2}$-fixation [27].

Table 2. Soil test results before seeding soybean at all environments in 2017 and 2018.

\begin{tabular}{|c|c|c|c|c|c|c|c|}
\hline Year & Location & Sampling Depth & $\mathrm{NO}_{3}-\mathrm{N}$ & $\mathbf{P}^{+}$ & $\mathbf{K}$ & $\mathrm{pH}$ & OM \\
\hline & & $\mathrm{cm}$ & $\mathrm{kg} \cdot \mathrm{ha}^{-1}$ & & -1 & & $\mathrm{~g} \cdot \mathrm{kg}^{-1}$ \\
\hline \multirow{2}{*}{2017} & Fargo & $0-15$ & 8 & 15 & 440 & 7.9 & 55 \\
\hline & & $15-61$ & 7 & 6 & 330 & 8.0 & 36 \\
\hline \multirow[t]{2}{*}{2017} & Fargo tile drained & $0-15$ & 5 & 16 & 432 & 7.9 & 55 \\
\hline & & $15-61$ & 5 & 6 & 290 & 8.2 & 35 \\
\hline \multirow[t]{2}{*}{2017} & Casselton & $0-15$ & 30 & 39 & 313 & 7.7 & 43 \\
\hline & & $15-61$ & 104 & 31 & 290 & 7.9 & 36 \\
\hline \multirow[t]{2}{*}{2018} & Fargo & $0-15$ & 19 & 9 & 330 & 7.8 & 56 \\
\hline & & $15-61$ & 79 & 4 & 286 & 8.1 & 36 \\
\hline \multirow[t]{2}{*}{2018} & Fargo tile drained & $0-15$ & 20 & 13 & 376 & 7.8 & 56 \\
\hline & & $15-61$ & 86 & 7 & 338 & 8.0 & 40 \\
\hline
\end{tabular}

${ }^{\dagger} \mathrm{P}$ based on the Olsen sodium bicarbonate extraction method, recommended for North Dakota soils [26], $\mathrm{OM}=$ organic matter.

The experimental design was a randomized complete block design with a split-plot arrangement with the row spacing as main plot. Within each main plot, there was a randomized factorial combination of two soybean relative maturities and three cover crop treatments. Plot row spacings were narrow $(30.5 \mathrm{~cm})$ or wide $(61 \mathrm{~cm})$. Soybean relative maturities were early (0.5) or late (0.9) [28]. Cover crop treatments were no cover crop, winter camelina, and winter rye. The experimental unit size was 1.5 by $7.6 \mathrm{~m}$.

In addition to the interseeding part of the study, eight plots within each replicate were used to represent growth of each cover crop after removing the soybean plants just before interseeding the cover crops to simulate cover crops growth without soybean competition for light, soil water, and nutrients. The treatments were designated as 'Soy' for plots without soybean biomass removed and 'No-soy' for plots with soybean biomass removed.

Narrow-row plots (30.5 cm row spacing) had four soybean rows seeded with a Hege 1000 no-till planter (Hege Company, Waldenberg, Germany). Wide-row plots were planted with the same planter at $61 \mathrm{~cm}$ row spacing. The seeding rate was 469,300 live seeds ha ${ }^{-1}$. The early-maturity soybean cultivar used was Asgrow brand "AG0536", which has a relative maturity of 0.5, and for the late maturity, the cultivar was Asgrow 'AG0934,' which has a relative maturity of 0.9 . They both are 'Roundup Ready 2 Yield soybeans' (glyphosate, $\mathrm{N}$-(phosphonomethyl) glycine) (Bayer, St. Louis, MO, USA), with resistance to soybean cyst nematode (Heterodera glycines) and Phytophthora spp., and the seed was coated by the company with Acceleron (a.i. pyraclostrobin and metalaxyl) (Bayer, St. Louis, MO, USA) seed treatment. Both cultivars were inoculated with Vault SP (Bradyrhizobium japonicum) (BASF, Ludwigshafen, Germany) at a rate of $1.8 \mathrm{~g} \cdot \mathrm{kg}^{-1}$ soybean seed.

Four 'No-soy' plots were grown with the early-maturity soybean cultivar and four with the late-maturity cultivar. Upon reaching the R6 growth stage [29] in the early- and the late-maturing soybeans, plants were removed by a sickle-bar mower (Troy-bilt, Valley City, OH, USA), which cut soybean plants $3 \mathrm{~cm}$ above soil surface. Then, cover crops were seeded in the 'No-soy' and interseeded in the 'Soy' experimental units, when the soybean was in R6 stage of development; dates varied based on relative maturity of the cultivar, as indicated in Table 3. Winter rye cultivar 'Rymin' with a 1000 seed weight of $33 \mathrm{~g}$ was seeded at $67 \mathrm{~kg}$ live seeds ha ${ }^{-1}$. Winter camelina cultivar 'Joelle' with a 1000 seed weight of $1.1 \mathrm{~g}$ was seeded at $10 \mathrm{~kg}$ live seeds ha ${ }^{-1}$. 
Table 3. Dates of important measurements and field operations at Fargo and Casselton, ND in 2017, 2018 , and 2019.

\begin{tabular}{|c|c|c|c|}
\hline Measurement/Operation & Fargo & Casselton & Fargo \\
\hline & 2017 & 2017 & 2018 \\
\hline Soybean planting & 8 May & 10 May & 14 May \\
\hline First herbicide application & 12 June & 12 June & 13 June \\
\hline Second herbicide application & 7 July & 7 July & 2 July \\
\hline Insecticide application & 25 August & 25 August & 12 July, 11 August \\
\hline Early maturity soybean cover crop interseeding & 18 August & 17 August & 8 August \\
\hline Later maturity soybean cover crop interseeding & 24 August & 24 August & 22 August \\
\hline Cover crop emergence in early maturity soybean & 23 August & 22 August & 28 August \\
\hline Cover cop emergence in later maturity soybean & 20 September & 21 September & 3 September \\
\hline Cover crop Canopeo ${ }^{\dagger}$ measurements & 31 October & 3 November & 21 October \\
\hline Cover crop biomass sampling & 1 November & 2 November & 22 October \\
\hline Cover crop stand counts & 13 October & 12 October & 22 October \\
\hline \multirow[t]{2}{*}{ Soybean harvest } & 6 October & 4 October & 18 September \\
\hline & 2018 & 2018 & 2019 \\
\hline Spring cover crop Canopeo & 12 May & 13 May & 12 May \\
\hline Spring cover crop biomass sampling & 12 May & 13 May & 12 May \\
\hline Spring wheat planting & 16 May & $-\ddagger$ & 31 May \\
\hline Spring wheat Canopeo & 13 June & - & 16 June \\
\hline Spring wheat herbicide application & 13 June & - & 2 July \\
\hline Wheat harvest & 17 August & - & 6 September \\
\hline
\end{tabular}

${ }^{\dagger}$ Canopeo $=$ tool for calculating soil green cover percentage. ${ }^{\ddagger}$ No wheat was planted at Casselton in 2018.

For wide-row plots, cover crops were planted in two parallel rows with a customized two-blade V-hoe spaced to make parallel furrows $15.3 \mathrm{~cm}$ apart. The parallel rows were planted in the two-center soybean rows. A single additional cover crop row was planted $15.3 \mathrm{~cm}$ from a soybean row, resulting in three cover crop rows in each experimental unit. For the narrow row spacing, a single furrow was made in the center between all soybean rows, $15.3 \mathrm{~cm}$ from each corresponding row, resulting in three cover crop rows. Furrows were made to the depths of $2.5 \mathrm{~cm}$ for rye and $1.3 \mathrm{~cm}$ for camelina.

Weeds in soybean were controlled during the vegetative growth stage using two applications of Roundup PowerMAX (a.i. 48.7\% glyphosate, N-(phosphonomethyl) glycine (Bayer, St. Louis, MO, USA). The herbicide was applied using TeeJet AIXR 110015 nozzles (TeeJet Technologies, Springfield, IL, USA) at a rate of $1.6 \mathrm{~L} \mathrm{ha}^{-1}$ in $94 \mathrm{~L} \mathrm{ha}^{-1}$ water and a spray pressure of $200 \mathrm{kPa}$. Hand weeding was used when needed to control weed escapes. Disease and insect pressure were monitored throughout the season, and Mustang Max (a.i. 9.15\% Zeta-cypermetrin*S-Cyano) (FMC Corporation, Philadelphia, PA, USA) foliar insecticide was used against soybean aphid (Aphis glycines Matsumura) at a rate of $292 \mathrm{~mL} \mathrm{ha}^{-1}$.

Before seeding hard red spring wheat (HRSW), in the spring following soybean, cover crops were terminated using one application of Roundup PowerMAX as described previously.

In 2018, the HRSW cultivar 'Glenn' was used, and in 2019, the cultivar used was 'SY Ingmar'. Spring wheat was planted in the two Fargo experiments in the springs of 2018 and 2019. Wheat was planted with a Great Plains 3P605NT no-till planter (Great Plains $\mathrm{Ag}$, Salina, KS, USA) as soon as field conditions were favorable in early May, with seven rows spaced $18.3 \mathrm{~cm}$ apart using a seeding rate of 2,739,000 live seeds $\mathrm{ha}^{-1}$. Seeds were planted to a depth of approximately $2 \mathrm{~cm}$. Nitrogen (N) was applied at a rate of $120 \mathrm{~kg}$ and $130 \mathrm{~kg} \cdot \mathrm{ha}^{-1}$ in 2018 and 2019, respectively.

Weeds were controlled with a foliar applied herbicide sprayed at $200 \mathrm{kPa}$ using TeeJet 8001 XR nozzles (TeeJet Technologies, Springfield, IL, USA) using $94 \mathrm{~L} \mathrm{ha}^{-1}$ water. In 2018, Wolverine Advanced (a.i 4.56\% fenoxaprop-p-ethyl, 6.13\% bromoxynil octanoate, 5.93\% bromoxynil heptanoate, $1.5 \%$ pyrasulfotole) (Bayer, St. Louis, MO, USA) was used at a rate of $2 \mathrm{~L} \mathrm{ha}^{-1}$. In 2019, Supremacy (a.i 36\% fluroxypry, 4.5\% thifensulfuron-methyl, 1.5\% tribenuron) (Arysta LifeSciences, Cary, NC, USA) at a rate of $439 \mathrm{~mL} \mathrm{ha}^{-1}$ and Axial XL (a.i. 5.05\% pinoxaden) (Syngenta, Greensboro, NC, USA) at a rate of $1.2 \mathrm{~L} \mathrm{ha}^{-1}$. 
Soybean and wheat were harvested after physiological maturity $[29,30]$ using a Wintersteiger Classic plot combine (Wintersteiger, Austria). Seeds were cleaned using a seed cleaner (Ferrell-Ross, Bluffton, IN, USA). Then, seed samples were weighed on a Mettler Toledo XS6001S scale (Mettler-Toledo, LLC, Columbus, OH, USA). Seed moisture and test weight were determined using a GAC 2100 moisture tester (DICKEY-John Corp., Minneapolis, MN, USA). Seed yield was corrected to 130 and $135 \mathrm{~g} \cdot \mathrm{kg}^{-1}$ moisture content for soybean and wheat, respectively.

\subsection{Data Collection}

Cover crop plants were counted within the center two rows of soybeans. Sampling areas were $50 \mathrm{~cm} \times 30.5 \mathrm{~cm}$ for narrow row plots and $25 \mathrm{~cm} \times 61 \mathrm{~cm}$ for wide row plots. Cover crop plants were counted in the fall after all rye and camelina plants emerged.

Soil green cover percentage was measured using the mobile phone application Canopeo (Oklahoma State University, Stillwater, OK, USA) before the first killing frost in the fall and before cover crop termination the following spring. Pictures uploaded into the Canopeo app were taken in the center of each plot at a height of $1 \mathrm{~m}$, allowing $15 \mathrm{~cm}$ from the outside of the last soybean row [31].

Cover crop biomass was harvested both in the fall and the spring. In the fall, harvest was done before the first killing frost; in the following spring, it was done preceding cover crop termination. Biomass was sampled from an area of $1 \mathrm{~m}$ by $30 \mathrm{~cm}$. Cover crop plants were cut at the base of plants nearest to soil. Samples were then placed in a dryer at a temperature of $40^{\circ} \mathrm{C}$. Samples were left in the dryer until constant weight was reached and were weighed.

Soil covered by spring wheat was measured using Canopeo during the tillering in mid-June (Table 3). Pictures used for soil green cover were taken in the center of each plot at a height of $1 \mathrm{~m}$.

\subsection{Statistical Analysis}

Statistical analysis was conducted according to the experimental design. All dependent variables were analyzed with a mixed model (PROC MIXED) on SAS 9.4 [32]. Row spacing, cultivar, and cover crops were analyzed as fixed variables. For the analysis for cover crops traits, the data from the treatment without cover crop interseeded into soybean were removed.

Environment was a random variable in the model. Treatment means were separated using Fisher's protected least significant difference (LSD) at a 5\% level of significance. The LSDs were calculated for the combined analysis across environments.

Data from plots with soybean biomass removed, designated as 'No-soy', and without biomass removed, designated as 'Soy', were analyzed separately with a mixed model (PROC MIXED) on SAS 9.3, as described previously. No differences were observed between row spacings for 'No-soy' plots, and data were combined across row spacing for further analysis. Cultivar differences were also not available since soybean biomass was removed, eliminating the differences in soybean plant senescence differences.

\section{Results and Discussion}

\subsection{Cover Crops Emergence}

Emergence of cover crops varied greatly with location and year. The 2017 growing season consistently had below average monthly precipitation when compared with historical averages. The only month with above average precipitation was September, which is a critical month for cover crop growth before going dormant in the fall. The early-soybean maturity cover crop planting date in 2017 was 17 August at Casselton and 18 August at Fargo. Precipitation of $5.9 \mathrm{~mm}$ was received on 16 August, resulting in ideal conditions for the first planting dates at both locations. Following cover crop planting, no precipitation event greater than $2.5 \mathrm{~mm}$ occurred until 15 September. This resulted in no germination of the second cover crop planting date until 20 and 21 September (Table 4). 
Table 4. Monthly total precipitation, average air temperature, and historical data at Fargo and Casselton, ND, 2017, 2018, and 2019.

\begin{tabular}{|c|c|c|c|c|c|c|c|c|c|c|c|c|}
\hline \multirow{3}{*}{ Month } & \multicolumn{8}{|c|}{ Fargo } & \multicolumn{4}{|c|}{ Casselton } \\
\hline & \multicolumn{2}{|c|}{2017} & \multicolumn{2}{|c|}{2018} & \multicolumn{2}{|c|}{2019} & \multicolumn{2}{|c|}{ Historical ${ }^{\dagger}$} & \multicolumn{2}{|l|}{2017} & \multicolumn{2}{|c|}{ Historical } \\
\hline & $\mathrm{mm}$ & ${ }^{\circ} \mathrm{C}$ & $\mathrm{mm}$ & ${ }^{\circ} \mathrm{C}$ & $\mathrm{mm}$ & ${ }^{\circ} \mathrm{C}$ & $\mathrm{mm}$ & ${ }^{\circ} \mathrm{C}$ & $\mathrm{mm}$ & ${ }^{\circ} \mathrm{C}$ & $\mathrm{mm}$ & ${ }^{\circ} \mathrm{C}$ \\
\hline April & 25 & 7.6 & 6 & 1.7 & 25 & 4.0 & 35 & 6.8 & 17 & 6.6 & 37 & 6.3 \\
\hline May & 26 & 14.0 & 44 & 18.0 & 70 & 8.6 & 71 & 14.0 & 17 & 13.2 & 77 & 13.4 \\
\hline June & 57 & 19.8 & 123 & 21.4 & 83 & 16.3 & 99 & 19.0 & 88 & 19.1 & 100 & 18.7 \\
\hline July & 23 & 22.3 & 81 & 21.7 & 121 & 21.3 & 71 & 21.6 & 50 & 21.2 & 88 & 21.3 \\
\hline August & 58 & 19.3 & 101 & 20.6 & 90 & 19.3 & 65 & 20.7 & 53 & 18.1 & 67 & 20.4 \\
\hline September & 70 & 16.5 & 64 & 15.0 & 107 & 16.6 & 65 & 15.1 & 152 & 15.3 & 66 & 14.8 \\
\hline October & 20 & 8.7 & 58 & 4.4 & 88 & 7.9 & 55 & 7.5 & 7 & 7.5 & 62 & 7.3 \\
\hline Total & 280 & - & 477 & - & 584 & - & 461 & - & 366 & - & 496 & - \\
\hline
\end{tabular}

${ }^{+}$Historical data represent a 30 year average 1981-2010 [25].

Since no precipitation was received for over a month, early-planted cover crops struggled to survive. High crop residue from soybean leaf senescence also greatly inhibited the growth of the early-planted cover crops, as it smothered the plants. Once the plants were smothered, the drought stress was compounded and resulted in retarded growth or cover crop plant death. Peterson et al. [20] stated that rapid soybean leaf senescence can also stress winter camelina plants, as cover crop plants can acclimate to low light conditions of less than $20 \%$ photosynthetically active radiation (PAR) under the canopy, and with rapid leaf drop, cover crop plants were not able to adapt to higher solar radiation. The late-planted cover crops emerged following soybean senescence and were able to germinate through the crop residue.

The 2018 growing season had above average rainfall following both cover crop planting dates, resulting in more developed cover crops during soybean senescence. This allowed the cover crops to handle the substantial amount of soybean residue produced during senescence compared with the 2017 growing season.

Monthly average air temperatures were $4{ }^{\circ} \mathrm{C}$ and $2.4{ }^{\circ} \mathrm{C}$ higher in the months of May and June in 2018 compared with the historical average, providing the soybean crop a good start to the season (Table 4).

During the late-planting date in 2017 and both planting dates in 2018, soybean senescence coincided with cover crop emergence. Soybean leaves completely covered the small seedlings of camelina. The rye was able to emerge from soybean leaf residue quickly due to rapid leaf growth and height of the plant compared with the prostrate rosette leaf arrangement produced from winter camelina.

\subsubsection{Presence and Absence of Soybean}

The analysis of variance indicated that conditions ('Soy' and 'No-Soy) and cover crop main effects were significant for all metrics except spring biomass (Table 5). Only significant effects in the analysis of variance are discussed herein. Significant interactions between a fixed and a random effect (environment) are not discussed.

Although removal of soybean plants resulted in higher soil cover and biomass compared with the 'Soy' treatment in the fall, the cover crops spring biomass from the 'No-soy' plots was 77\% of the biomass recorded in the 'No-soy' plots in the fall (Table 6). The lower amount of biomass in the spring can be attributed to winterkill. Winter camelina loses the ability to survive the winter if it produces a relatively high amount of biomass or is seeded before 15 September in the fall [16].

'No-soy' plots were designed to simulate an environment for cover crop growth without light, nutrient, or water competition from soybean plants. The interseeded cover crops at the R6 growth stage of soybean were competing with fully established soybean plants for sunlight. This resulted in reduced cover crop stand and growth established in the fall compared to cover crops grown without soybean. 
Table 5. Mean squares for two soybean conditions ('Soy' and 'No-Soy') and two cover crops (CC) in five environments at Fargo and Casselton, ND, 2017, 2018, and 2019.

\begin{tabular}{|c|c|c|c|c|c|c|}
\hline $\mathrm{SOV}^{+}$ & df & $\begin{array}{c}\text { Fall Soil Cover } \\
2017-2018\end{array}$ & $\begin{array}{c}\text { Spring Soil Cover } \\
2018-2019\end{array}$ & $\begin{array}{c}\text { Fall Biomass } \\
2017-2018\end{array}$ & $\begin{array}{c}\text { Spring Biomass } \\
2018-2019\end{array}$ & $\begin{array}{c}\text { Fall CC Stand Count } \\
2017-2018\end{array}$ \\
\hline & & $\%$ & $\%$ & $\mathrm{~kg} \cdot \mathrm{ha}^{-1}$ & $\mathrm{~kg} \cdot \mathrm{ha}^{-1}$ & Plants $\mathrm{m}^{-2}$ \\
\hline Env & 4 & 0.216 & 0.128 & 2015.1 * & 3798.5 * & 2514 \\
\hline $\operatorname{Rep}(\mathrm{env})$ & 15 & 0.069 * & 0.068 * & $178.4^{*}$ & 48.1 & 1484 * \\
\hline Cond. & 1 & 2.187 * & 1.930 * & 3986.2 * & 812.1 & 59,245 * \\
\hline Env $\times$ Cond & 4 & 0.053 & 0.029 & 312.1 & 511.3 & 437 \\
\hline $\mathrm{CC}$ & 1 & 0.947 * & 0.539 * & $2353.9 *$ & $1584.5 *$ & 31,972 * \\
\hline Env $\times \mathrm{CC}$ & 4 & 0.059 & 0.063 & 164.0 & 145.9 & 385 \\
\hline Cond. $\times$ CC & 1 & 0.098 & 0.037 & 4.8 & 61.8 & 11,846 \\
\hline Env $\times$ Cond $\times$ CC & 4 & 0.022 & 0.021 & $137.2 *$ & 112.7 * & 1408 * \\
\hline Residual & 46 & 0.011 & 0.011 & 32.8 & 45.5 & 345 \\
\hline
\end{tabular}

${ }^{\dagger} \mathrm{SOV}=$ sources of variation. Cond. = soybean conditions ('Soy' and 'No-Soy'), CC = cover crops (winter rye and camelina), Env = environment. ${ }^{*}=$ significant at $(p \leq 0.05)$.

Table 6. Mean fall and spring cover crop soil green cover, biomass, and stand count in treatments with and without soybean averaged across row spacing and maturity across five environments at Fargo and Casselton, ND, 2017, 2018 , and 2019.

\begin{tabular}{|c|c|c|c|c|c|}
\hline Treatment & $\begin{array}{c}\text { Fall Soil Cover } \\
2017-2018\end{array}$ & $\begin{array}{c}\text { Spring Soil Cover } \\
2018-2019\end{array}$ & $\begin{array}{l}\text { Fall Biomass } \\
2017-2018\end{array}$ & $\begin{array}{c}\text { Spring Biomass } \\
2018-2019\end{array}$ & $\begin{array}{l}\text { Fall Stand Counts } \\
2017-2018\end{array}$ \\
\hline & $\%$ & $\%$ & $\mathrm{~kg} \cdot \mathrm{ha}^{-1}$ & $\mathrm{~kg} \cdot \mathrm{ha}^{-1}$ & plants $\mathrm{m}^{-2}$ \\
\hline 'Soy' & $8.1 \mathrm{~b}^{\dagger}$ & $14.0 \mathrm{~b}$ & $158 b$ & $202 a$ & $75 b$ \\
\hline ‘No-soy' $\ddagger$ & $24.7 \mathrm{a}$ & $29.6 a$ & $410 \mathrm{a}$ & $316 a$ & $167 a$ \\
\hline
\end{tabular}

${ }^{\dagger}$ Means followed by a different small case letter within a column are different at $p \leq 0.05 .{ }^{\ddagger}$ Experimental units had soybean biomass removed at the time of cover crop seeding.

3.1.2. Cover Crops Fall and Spring Coverage and Biomass in Treatments with No Soybean ('No-Soy')

Winter camelina had lower cover percent and biomass compared with rye in both the fall and the spring (Table 7). Winter camelina had a slower establishment period, which set the plant behind compared with rye. Rye had higher soil coverage and biomass compared with camelina biomass, as was also reported in other research $[15,20,21]$. while winter camelina had more plants compared with rye. Rye produced only some tillers in the fall. and camelina stayed in the rosette stage and had limited foliar growth.

Table 7. Mean fall and spring cover crop soil cover, cover crop biomass. and cover crop stand counts for two cover crops averaged across conditions and environments at Fargo and Casselton, ND, 2017, 2018, and 2019.

\begin{tabular}{cccccc}
\hline Cover Crop & Fall Soil Cover & Spring Soil Cover & Fall Biomass & Spring Biomass & Fall Stand Counts \\
& $\mathbf{2 0 1 7 - 2 0 1 8}$ & $\mathbf{2 0 1 8 - 2 0 1 9}$ & $\mathbf{2 0 1 7 - 2 0 1 8}$ & $\mathbf{2 0 1 8 - 2 0 1 9}$ & $\mathbf{2 0 1 8}$ \\
\hline & $\%$ & $\%$ & $\mathrm{~kg}^{-\mathrm{ha}^{-1}}$ & $\mathrm{~kg} \cdot \mathrm{ha}^{-1}$ & $\mathrm{plants} \mathrm{m}^{-2}$ \\
Winter camelina & $10.9 \mathrm{~b}^{+}$ & $17.7 \mathrm{~b}$ & $315 \mathrm{~b}$ & $223 \mathrm{~b}$ & $154 \mathrm{a}$ \\
Winter rye & $21.8 \mathrm{a}$ & $25.9 \mathrm{a}$ & $505 \mathrm{a}$ & $410 \mathrm{a}$ & $89 \mathrm{~b}$ \\
\hline
\end{tabular}

${ }^{\dagger}$ Means with a different small case letters within a column are different at $p \leq 0.05$.

\subsection{Cover Crops Soil Green Cover and Biomass in Treatments Interseeded into Soybean}

The analysis of variance indicated that the soybean yield was significantly different for row spacing, but none of the cover crop metrics were significantly different (Table 8). The differences in soybean maturity and cover crop type resulted in significant observed differences. 
Table 8. Mean square values for row spacing (RS), maturity (Mat), cover crop (CC), and five environments (Env) at Fargo, ND, 2017, 2018.

\begin{tabular}{|c|c|c|c|c|c|c|c|c|c|c|}
\hline $\mathrm{SOV}^{\dagger}$ & df & $\begin{array}{l}\text { CC Fall Soil } \\
\text { Cover } \\
\text { 2017-2018 }\end{array}$ & $\begin{array}{c}\text { CC Spring Soil } \\
\text { Cover } \\
\text { 2018-2019 }\end{array}$ & $\begin{array}{c}\text { CC Fall } \\
\text { Biomass } \\
\text { 2017-2018 }\end{array}$ & $\begin{array}{c}\text { CC Spring } \\
\text { Biomass } \\
2018-2019\end{array}$ & $\begin{array}{c}\text { Fall CC Stand } \\
2017-2018\end{array}$ & $\begin{array}{c}\text { Soybean Yield } \\
\text { 2017-2018 }\end{array}$ & df & $\begin{array}{l}\text { Wheat Yield } \\
\text { 2018-2019 }\end{array}$ & $\begin{array}{l}\text { Wheat Soil } \\
\text { Cover } \\
\text { 2018-2019 }\end{array}$ \\
\hline & & $\%$ & $\%$ & $\mathrm{~kg} \cdot \mathrm{ha}^{-1}$ & $\mathrm{~kg} \cdot \mathrm{ha}^{-1}$ & plants $\mathrm{m}^{-2}$ & $\mathrm{~kg} \cdot \mathrm{ha}^{-1}$ & & $\mathrm{~kg} \cdot \mathrm{ha}^{-1}$ & $\%$ \\
\hline Env & 4 & 0.0323 & 0.0223 & 633.7 & 820.3 * & 564 & $6,531,173$ * & 3 & $22,543,640 *$ & 0.4332 \\
\hline $\operatorname{Rep}(\mathrm{env})$ & 15 & 0.0149 * & 0.0218 * & $57.8 *$ & $57.8 *$ & 736 & $598,695 *$ & 12 & $665,821 *$ & 0.1535 \\
\hline RS & 1 & 0.0101 & 0.0004 & 28.4 & 37.7 & 52 & $1,983,581$ * & 1 & $1,241,365$ & 0.0984 \\
\hline Env $\times$ RS & 4 & 0.0031 & 0.0028 & 10.4 & 26.8 & 79 & 205,522 & 3 & 312,542 & 0.0087 \\
\hline Mat & 1 & $0.1461 *$ & $0.3152 *$ & 199.5 & $64.1 *$ & $7886^{*}$ & $1,131,392$ * & 1 & $1,312,528$ & 0.5355 \\
\hline $\mathrm{CC}$ & 1 & 0.2191 * & 0.1503 * & $1055.7^{*}$ & $505.8 *$ & $2540 *$ & 57,963 & 2 & $857,852 *$ & $0.4897^{*}$ \\
\hline Env $\times \mathrm{CC}$ & 4 & 0.0488 * & 0.0643 * & $260.3 *$ & $97.5 *$ & $912 *$ & 237,473 & 6 & $56,851 *$ & 0.1141 * \\
\hline $\mathrm{RS} \times \mathrm{CC}$ & 1 & 0.0024 & 0.0015 & 4.5 & 2.5 & 34 & 57,708 & 2 & 66,563 & 0.0089 \\
\hline Env $\times$ RS $\times$ CC & 4 & 0.0015 & 0.0017 & 4.0 & 5.3 & 96 & 109,773 & 6 & 141,523 & 0.0101 \\
\hline $\mathrm{RS} \times$ Mat & 1 & 0.0024 & 0.0043 & 10.6 & 29.6 & 2 & 4621 & 1 & 595 & 0.0055 \\
\hline Env $\times$ RS $\times$ Mat & 4 & 0.0014 & 0.0049 & 10.7 & 49.5 & 152 & 55,564 & 3 & 74,852 & 0.0098 \\
\hline $\mathrm{CC} \times$ Mat & 1 & 0.0484 & 0.0347 & 95.6 & 78.9 & 218 & 621,545 & 2 & 565,624 & 0.4685 \\
\hline Env $\times \mathrm{CC} \times$ Mat & 15 & 0.0048 & 0.0074 & 6.8 & 8.1 & $491 *$ & 148,295 & 6 & 132,456 & 0.0145 \\
\hline $\mathrm{RS} \times$ Mat $\times \mathrm{CC}$ & 1 & 0.0025 & 0.0016 & 28.4 & 25.7 & 139 & 21,513 & 2 & 32,524 & 0.0075 \\
\hline Residual Error & 90 & 0.0031 & 0.0060 & 13.3 & 16.1 & 215 & 149,295 & 133 & 178,325 & 0.0098 \\
\hline
\end{tabular}

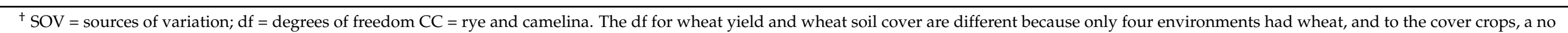
cover crop treatment was added to the analysis * $=$ significant at $p \leq 0.05$. 
The experiment was set up to investigate if there were any interactions between main factors, however, the ANOVA indicated that there was no interaction between soybean row spacing and cover crops, soybean maturity and cover crops, or the three way interaction of soybean row spacing by maturity by cover crops for any of the measured observations.

Only significant effects in the analysis of variance are discussed herein. Significant interactions between a fixed and a random effect (environment) are not discussed.

\subsubsection{Row Spacing Effect}

Narrow-row spacing produced higher soybean yield compared with wide-row spacing (Table 9). Previous research in the NWCB also reported higher soybean yields with narrowrow spacing $[33,34]$. This soybean yield difference may be due to the decreased total light absorption by the soybean plants in wider rows and/or competition for nutrients and water with higher plant density within rows in wider rows.

Table 9. Soybean seed yield, fall and spring cover crop soil green cover, cover crop biomass, and cover crop stand count readings for two row spacings averaged across cover crops and relative maturity across five environments planted at Fargo and Casselton, ND, 2017, 2018, and 2019.

\begin{tabular}{ccccccc}
\hline \multirow{2}{*}{ Row Spacing } & $\begin{array}{c}\text { Soybean Yield } \\
\mathbf{2 0 1 7 - 2 0 1 8}\end{array}$ & $\begin{array}{c}\text { Fall Soil Cover } \\
\text { 2017-2018 }\end{array}$ & $\begin{array}{c}\text { Spring Soil Cover } \\
\mathbf{2 0 1 8 - 2 0 1 9}\end{array}$ & $\begin{array}{c}\text { Fall Biomass } \\
\text { 2017-2018 }\end{array}$ & $\begin{array}{c}\text { Spring Biomass } \\
\mathbf{2 0 1 8 - 2 0 1 9}\end{array}$ & $\begin{array}{c}\text { Fall Stand Count } \\
\mathbf{2 0 1 7 - 2 0 1 8}\end{array}$ \\
\hline & $\mathrm{kg} \cdot \mathrm{ha}^{-1}$ & $\%$ & $\%$ & $\mathrm{~kg}^{-} \mathrm{ha}^{-1}$ & $\mathrm{~kg}^{-1} \mathrm{ha}^{-1}$ & $\mathrm{plants} \mathrm{m}^{-2}$ \\
Wide $(61 \mathrm{~cm})$ & $2287 \mathrm{~b}^{+}$ & 8.9 & 14.1 & 171 & 220 & 79 \\
Narrow $(30.5 \mathrm{~cm})$ & $2467 \mathrm{a}$ & 7.3 & 13.9 & 141 & 184 & 81 \\
\hline
\end{tabular}

${ }^{\dagger}$ Means with different letters are different at $p \leq 0.05$. If letters are absent, they are not significantly different.

Based on this research, narrow row-soybean planting is recommended since cover crop differences were non-significant between row spacings. This difference of $180 \mathrm{~kg} \cdot \mathrm{ha}^{-1}$ higher yield in narrower rows results in a net income gain of $\$ 52.9 \mathrm{ha}^{-1}$ when using a soybean price of $\$ 0.29 \mathrm{~kg}^{-1}$ when comparing $30.5 \mathrm{~cm}$ with $61 \mathrm{~cm}$ row spacing. The net loss for wider rows would be difficult to justify since the cover crop biomass production was not different at either row spacing (Table 9).

\subsubsection{Relative Maturity of Cultivars Effects}

Where the cover crop was interseeded earlier (in the early maturing cultivar), fall and spring cover crop soil cover percentages were higher, as were fall biomass, spring biomass, and stand counts (Table 10).

Table 10. Soybean yield, fall and spring cover crop canopy coverage, cover crop biomass, and cover crop stand count readings for two cultivars averaged across five environments in Fargo and Casselton, ND, from 2017, 2018, and 2019.

\begin{tabular}{|c|c|c|c|c|c|c|}
\hline Cultivar & $\begin{array}{c}\text { Soybean Yield } \\
2017-2018\end{array}$ & $\begin{array}{c}\text { Fall Soil Cover } \\
2017-2018\end{array}$ & $\begin{array}{c}\text { Spring Soil Cover } \\
2018-2019\end{array}$ & $\begin{array}{c}\text { Fall biomass } \\
2017-2018\end{array}$ & $\begin{array}{c}\text { Spring Biomass } \\
2018-2019\end{array}$ & $\begin{array}{c}\text { Fall Stand Count } \\
2017-2018\end{array}$ \\
\hline & $\mathrm{kg} \cdot \mathrm{ha}^{-1}$ & $\%$ & $\%$ & $\mathrm{~kg} \cdot \mathrm{ha}^{-1}$ & $\mathrm{~kg} \cdot \mathrm{ha}^{-1}$ & plants $\mathrm{m}^{-2}$ \\
\hline $\begin{array}{c}\text { Early } \\
\text { maturing } \\
\text { (AG0536) }\end{array}$ & $2308 b^{\dagger}$ & $11.1 \mathrm{a}$ & $18.4 \mathrm{a}$ & $193 a$ & $226 a$ & $98 a$ \\
\hline $\begin{array}{l}\text { Late maturing } \\
\text { (AG0934) }\end{array}$ & $2445 a$ & $5.0 \mathrm{~b}$ & $9.6 \mathrm{~b}$ & $118 b$ & $180 \mathrm{~b}$ & $52 b$ \\
\hline
\end{tabular}

${ }^{+}$Means followed by a different letter within a column are significantly different at $p \leq 0.05$.

The later maturing soybean cultivar ( 0.9 vs. 0.5 maturity group) produced significantly higher soybean yields with an average difference of $137 \mathrm{~kg} \cdot \mathrm{ha}^{-1}$ relative to the earlier maturity soybean (Table 10). In other studies, higher yields for later maturing soybean cultivars in US soybean growing regions, including North Dakota, were also reported [34,35]. The difference of $137 \mathrm{~kg} \cdot \mathrm{ha}^{-1}$ in this study resulted in a per hectare reduced income of 
$\$ 42.26 \mathrm{ha}^{-1}$ when using $\$ 0.294 \mathrm{~kg}^{-1}$ soybean price when the earlier maturing cultivar was used compared with the later maturing cultivar.

\subsubsection{Cover Crop Effect}

Biomass produced by winter rye at all times (fall 2017 and 2018 and spring 2018 and 2019) was significantly higher compared with that of winter camelina. There were significantly more established camelina plants in the fall compared to winter rye. This is most likely a function of seeding rate (Table 11).

Table 11. Mean fall and spring cover crop soil coverage, cover crop biomass, and cover crop stand count readings for two cover crops averaged across five environments at Fargo and Casselton, ND, 2017, 2018, and 2019.

\begin{tabular}{ccccccc}
\hline Cover Crop & $\begin{array}{c}\text { Fall Soil Cover } \\
\text { 2017-2018 }\end{array}$ & $\begin{array}{c}\text { Spring Soil Cover } \\
\text { 2018-2019 }\end{array}$ & $\begin{array}{c}\text { Soybean Yield } \\
\text { 2017-2018 }\end{array}$ & $\begin{array}{c}\text { Fall Biomass } \\
\text { 2017-2018 }\end{array}$ & $\begin{array}{c}\text { Spring Biomass } \\
\text { 2018-2019 }\end{array}$ & $\begin{array}{c}\text { Fall Stand Count } \\
\text { 2017-2018 }\end{array}$ \\
\hline & $\%$ & $\%$ & $\mathrm{~kg} \cdot \mathrm{ha}^{-1}$ & $\mathrm{~kg} \cdot \mathrm{ha}^{-1}$ & $\mathrm{~kg} \cdot \mathrm{ha}^{-1}$ & $\mathrm{plants}^{-2}$ \\
Winter rye & $11.8 \mathrm{a}$ & $17.1 \mathrm{a}$ & 2367 & $242 \mathrm{a}$ & $259 \mathrm{a}$ & $62 \mathrm{~b}$ \\
Winter camelina & $4.4 \mathrm{~b}$ & $11.0 \mathrm{~b}$ & 2411 & $72 \mathrm{~b}$ & $144 \mathrm{~b}$ & $89 \mathrm{a}$ \\
\hline
\end{tabular}

${ }^{+}$Means followed by a different letter within a column are significantly different at $p \leq 0.05$.

These differences are consistent with 'No-soy' cover crop differences (Table 6). Spring soil cover in this study was similar to other studies for winter rye and camelina $[15,19,20]$. Another study suggested at least $30 \%$ of the soil surface should be covered to protect the soil from water and wind erosion [36]. There was not a significant difference in soybean yield when winter rye or camelina were interseeded.

\subsection{Wheat Yield}

Growing rye before planting wheat resulted in reductions in HRSW soil coverage and grain yield (Table 12). These differences were visually obvious and statistically significant, consistent with other research $[20,37]$, with rye reducing wheat canopy cover by almost $20 \%$ ( 51.1 vs. $41.0 \%$ ) and yield by $277 \mathrm{~kg} \cdot \mathrm{ha}^{-1}$ compared with wheat without previous cover crop (Table 12). When the overwintering winter rye resumed growth in the spring, the rye utilized nutrients and water, reducing the amount of available water for the subsequent spring wheat crop, which impacted development. It was reported that winter rye produces allelopathic compounds, which can affect wheat and other grasses growth [38], can carryover root diseases [39], and can immobilize N, which can negatively impact yield [40,41]. Wheat soil cover and wheat grain yield were similar after camelina compared with wheat after no cover crop in the soybean. This research shows that cover crops can be established in soybean and that there can be a negative effect on the subsequent crop. We terminated the cover crop at the same time as seeding wheat.

Table 12. Mean soybean yield for two cover crops averaged across five environments in Fargo and Casselton, ND, 2017 and 2018 , and mean wheat soil cover and yield across four environments in Fargo, ND, 2018 and 2019.

\begin{tabular}{cccc}
\hline Cultivar & $\begin{array}{c}\text { Wheat Soil Cover } \\
\mathbf{2 0 1 8 - 2 0 1 9}\end{array}$ & $\begin{array}{c}\text { Soybean Yield } \\
\mathbf{2 0 1 7 - 2 0 1 8}\end{array}$ & $\begin{array}{c}\text { Wheat Grain Yield } \\
\mathbf{2 0 1 8 - 2 0 1 9}\end{array}$ \\
\hline & $\%$ & $\mathrm{~kg} \cdot \mathrm{ha}^{-1}$ & $\mathrm{~kg} \cdot \mathrm{ha}^{-1}$ \\
Winter rye & $41.0 \mathrm{~b}^{+}$ & 2367 & $2534 \mathrm{~b}$ \\
Winter camelina & $52.3 \mathrm{a}$ & 2411 & $2783 \mathrm{a}$ \\
No cover crop & $51.1 \mathrm{a}$ & 2368 & $2811 \mathrm{a}$ \\
\hline
\end{tabular}

${ }^{\dagger}$ Means followed by a different letter within a column are significantly different at $p \leq 0.05$.

Future research could look at alternative termination methods and timings to reduce the negative effect of over-wintering rye on the following wheat crop. The other angle for additional research would be to evaluate other subsequent crops after interseeding rye into soybean, for instance, with flax (Linum usitatissimum L.) or forage crops. 


\section{Conclusions}

Winter rye or camelina interseeded in an early-maturing soybean (0.5) had higher biomass yield and soil green cover compared with the same crops interseeded in a later maturing (0.9) soybean. However, the yield penalty of planting an early-maturity soybean cultivar was higher in value than the value of increased cover crop growth and cover. The value of the soybean yield reduction $\left(137 \mathrm{~kg} \cdot \mathrm{ha}^{-1} \times\right.$ market price) between the two cultivars was significant. Based on the results of this study, planting an early-maturity soybean cultivar to allow more growth of interseeded cover crops is not recommended, as the loss of revenue is not compensated by an increase in cover crop biomass. In order to find out if long-term economic benefits from interseeding cover crops offset the yield reduction due to the utilization of an early-maturity cultivar, additional research is needed.

There was no significant difference in fall or spring biomass production with wide row spacing compared with the narrow row spacing. Thus, it is recommended to plant soybean in narrow row spacing $(30.5 \mathrm{~cm}$ compared with $61 \mathrm{~cm})$, as soybean yields were significantly higher with the narrower row spacing than wide row spacing. No soybean yield reduction was observed after the interseeding of the cover crops compared with soybean with no interseeded cover crop. This proves competition of cover crops with soybean plants when cover crops are seeded at the R6 growth stage of the soybean cultivars was negligible and that no economic soybean yield loss should be expected.

Seeding wheat on the same day as rye termination is not recommended. Winter rye reduced growth and grain yield of wheat. Our research indicates that there is an opportunity to establish winter rye by interseeding into soybean, but termination and subsequent crops selected need further investigation. Oppositely, interseeding winter camelina into soybean had no negative effects on wheat growth and yield. Thus, winter camelina can be utilized as a cover crop interseeded into soybean to follow a wheat crop the next growing season. However, biomass production and soil cover by camelina are probably not enough to keep the soil from blowing away. Future research should investigate if there is an economic benefit of adding camelina as a cover crop into soybean.

Author Contributions: H.J.K.: conceptualization, investigation, supervision, writing-review \& editing. D.P.S.: writing-review \& editing. K.L.J.: formal analysis, investigation, methodology, writing - original draft. M.T.B.: formal analysis, funding acquisition, investigation, project administration, resources, writing-review \& editing. All authors have read and agreed to the published version of the manuscript.

Funding: This project was funded by USDA-NIFA, Award no. 2016-69004-24784.

Data Availability Statement: Raw data is available upon request to H. Kandel. Data has not been archived in a repository.

Acknowledgments: The authors would like to thank Chad Deplazes and Darin Eisinger for their technical assistance.

Conflicts of Interest: The authors declare no conflict of interest.

\section{References}

1. O'Brien, P.; Hatfield, J.L.; Dodd, C.; Kistner-Thomas, E.J. Cropping pattern changes diminish agroecosystem services in North and South Dakota, USA. Agron. J. 2020, 112, 1-24. [CrossRef]

2. Dickey, E.C.; Shelton, D.P.; Jasa, P.J.; Peterson, T.R. Soil erosion form tillage systems used in soybean and corn residues. Trans. ASAE 1985, 28, 1124-1130. [CrossRef]

3. Snapp, S.; Swinton, S.; Labarta, R.; Mutch, D.; Black, J.; Leep, R.; Nyiraneza, J.; O’Neil, K. Evaluating cover crops for benefits, costs and performance within cropping system niches. Agron. J. 2005, 97, 322-332.

4. Lu, Y.C.; Watkins, K.B.; Teasdale, J.R.; Abdul-Baki, A.A. Cover crops in sustainable food production. Food Rev. Intern. 2000, 16, 121-157. [CrossRef]

5. Cecchin, A.; Pourhashem, G.; Gesch, R.W.; Lenssen, A.W.; Patel, S.; Berti, M.T. The environmental impact of ecological intensification of a cropping system in the U.S. Upper Midwest. Sustainability 2021, 13, 1696. [CrossRef]

6. Cecchin, A.; Pourhashem, G.; Gesch, R.W.; Lenssen, A.W.; Patel, S.; Berti, M.T. Environmental trade-offs of relay-cropping winter cover crops within maize and soybean. Agric. Syst. 2021, 189, 103062. [CrossRef] 
7. SARE (Sustainable Agriculture Research and Education). Annual Report, National Cover Crop Survey. 2020. Available online: https://www.sare.org/wp-content/uploads/2019-2020-National-Cover-Crop-Survey.pdf (accessed on 14 April 2021).

8. Plastina, A.; Liu, F.; Miguez, F.; Carlson, S. Cover crops use in Midwestern US agriculture: Perceived benefits and net returns. Renew. Agric. Food Syst. 2020, 35, 38-48. [CrossRef]

9. SARE (Sustainable Agriculture Research and Education). Managing Cover Crops Profitably, 3rd ed.; Handbook Serior 9; SARE: College Park, MD, USA, 2012; pp. 98-105.

10. Putnam, D.; Budin, J.; Field, L.; Breene, W. Camelina: A promising low-input oilseed. In New Crops, Exploration, Research and Commercialization, Proceedings of the Second National Symposium, Indianapolis, IN, USA, 6-9 October 1991; Janick, J., Simon, J.E., Eds.; John Wiley and Sons, Inc.: Hoboken, NJ, USA, 1993; pp. 314-322.

11. Zubr, J. Oil-seed crop: Camelina sativa. Ind. Crop. Prod. 1997, 6, 113-119. [CrossRef]

12. Berti, M.; Gesch, R.; Eynck, C.; Anderson, J.; Cermak, S. Camelina uses, genetics, genomics, production, and management. Ind. Crop. Prod. 2016, 94, 690-710. [CrossRef]

13. Gesch, R.W.; Archer, D.; Berti, M.T. Dual cropping winter camelina with soybean in the northern Corn Belt. Agron. J. 2014, 106, 1735-1745. [CrossRef]

14. Gesch, R.; Cermak, S. Sowing date and tillage effects on fall-planted camelina in the northern Corn Belt. Agron. J. 2011, 103, 980-987. [CrossRef]

15. Berti, M.; Samarappuli, D.; Johnson, B.L.; Gesch, R.W. Integrating winter camelina into maize and soybean cropping systems. Ind. Crop. Prod. 2017, 107, 595-601. [CrossRef]

16. Wittenberg, A.; Anderson, J.V.; Berti, M.T. Crop growth and productivity of winter camelina in response to sowing date. Ind. Crop. Prod. 2020, 158, 113036. [CrossRef]

17. Wilson, M.L.; Baker, J.M.; Allan, D.L. Factors affecting successful establishment of aerially seeded winter rye. J. Environ. Qual. 2013, 33, 1010. [CrossRef]

18. Crowley, K.A.; Van Es, H.M.; Gomex, M.I.; Ryan, M.R. Trade-offs in cereal rye management strategies prior to organically managed soybean. Agron. J. 2018, 110, 1492-1504. [CrossRef]

19. Kladivko, E.; Kaspar, T.; Jaynes, D.; Malone, R.; Singer, J.; Morin, X.; Searchinger, T. Cover crops in the upper Midwest USA: Potential adoption and reduction of nitrate leaching in the Mississippi River Basin. J. Soil Water Conserv. 2014, 69, $279-291$. [CrossRef]

20. Peterson, A.T.; Berti, M.T.; Samarappuli, D. Intersowing cover crops into standing soybean in the US Upper Midwest. Agronomy 2019, 9, 264. [CrossRef]

21. Mohammed, Y.A.; Matthees, H.L.; Gesch, R.W.; Patel, S.; Forcella, F.; Aasand, K.; Steffl, N.; Johnson, B.L.; Wells, M.S.; Lenssen, A.W. Establishing winter annual cover crops by interseeding into maize and soybean. Agron. J. 2020, 1-14. [CrossRef]

22. Johnson, K.L.; Kandel, H.J.; Samarappuli, D.P.; Berti, M.T. Interseeding camelina and rye in soybean with varying maturity provides soil cover without affectingsoybean yield. Agronomy 2021, 11, 353. [CrossRef]

23. Midwest Cover Crops Council. Integrating Cover Crops in Soybean Rotations: Challenges and Recommendations for the North Central Region. 2015. Available online: http:/ / mccc.msu.edu/wp-content/uploads/2016/10/ALL_2015_Integrating-covercrops-in-soybean-rotations.pdf (accessed on 14 April 2021).

24. USDA (United States Department of Agriculture). Web Soil Survey. 2021. Available online: https://websoilsurvey.sc.egov.usda. gov / App/HomePage.htm (accessed on 14 April 2021).

25. NDAWN. North Dakota Agricultural Weather Network; North Dakota State Univ.: Fargo, ND, USA, 2020; Available online: http:/ / ndawn.ndsu.nodak.edu (accessed on 14 April 2021).

26. Olsen, S.R.; Cole, C.V.; Watanabe, F.S.; Dean, L.A. Estimation of Available Phosphorus in Soils by Extraction with Sodium Bicarbonate; No. 939; US Department of Agriculture: Washington, DC, USA, 1954.

27. Franzen, D.; Goos, R.J.; Kandel, H.; Augustin, C.; Buetow, R.; Teboh, J.; Forster, S.; Endres, G. Soybean Soil Fertility; Ext. Pub. SF1164; North Dakota State Univ.: Fargo, ND, USA, 2019; Available online: https://www.ag.ndsu.edu/publications/crops/ soybean-soil-fertility\#section-3 (accessed on 14 April 2021).

28. Mourtzinis, S.; Conley, S.P. Delineating soybean maturity groups across the United States. Agron. J. 2017, 109, 1397-1403. [CrossRef]

29. Fehr, W.R.; Caviness, C.E.; Burmood, D.T.; Pennington, J.S. Stage of development descriptions for soybeans, Glycine max (L.) Merrill. Crop Sci. 1971, 11, 929-931. [CrossRef]

30. Zadoks, J.C.; Chang, T.T.; Konzak, C.F. A decimal code for the growth stages of cereals. Weed Res. 1974, 14, 415-421. [CrossRef]

31. Patrignani, A.; Ochsner, T.E. Canopeo: A powerful new tool for measuring fractional green canopy cover. Agron. J. 2015, 107, 2312-2320. [CrossRef]

32. SAS Institute. SAS User's Guide; Statistics; SAS Institute: Cary, NC, USA, 2020.

33. Andrade, J.F.; Rattalino Edreira, J.I.; Mourtzinis, S.; Conley, S.P.; Ciampitti, I.A.; Dunphy, J.E.; Gaska, J.M.; Glewen, K.; Holshouser, D.L.; Kandel, H.J.; et al. Assessing the influence of row spacing on US soybean seed yield using experimental and survey producer data. Field Crop. Res. 2019, 230, 98-106. [CrossRef]

34. Schmitz, P.K.; Stanley, J.D.; Kandel, H. Row spacing and seeding rate effect on soybean seed yield in North Dakota. Crop Forage Turfgrass Manag. 2020, 6, e20010. [CrossRef]

35. Egli, D.B. Cultivar maturity and potential yield of soybean. Field Crop. Res. 1993, 32, 147-158. [CrossRef] 
36. Allmaras, R.; Dowdy, R. Conservation tillage systems and their adoption in the United States. Soil Tillage Res. 1985, 5, 197-222. [CrossRef]

37. Nielsen, D.C.; Lyon, D.J.; Higgins, R.K.; Hergert, G.W.; Holman, J.D.; Vigil, M.F. Cover crop effect on subsequent wheat yield in the central Great Plains. Agron. J. 2016, 108, 243-256. [CrossRef]

38. Moyer, J.R.; Blackshaw, R.E. Fall-seeded cover crops after dry bean and potato in southern Alberta. Can. J. Plant Sci. 2009, 89, 133-139. [CrossRef]

39. Bakker, M.G.; Acharya, J.; Moorman, T.B.; Robertson, A.E.; Kaspar, T.C. The potential for cereal rye cover crops to host corn seedling pathogens. Phytopathology 2016, 106, 591-601. [CrossRef]

40. Thomas, B.W.; Larney, F.J.; Chantigny, M.H.; Goyer, C.; Hao, X.Y. Fall rye reduced residual soil nitrate and dryland spring wheat grain yield. Agron. J. 2017, 109, 718-728. [CrossRef]

41. Krueger, E.S.; Ochsner, T.E.; Porter, P.M.; Baker, J.M. Winter rye cover crop management influences on soil water, soil nitrate, and corn development. Agron. J. 2011, 103, 316-323. [CrossRef] 